\title{
Nitric Oxide, Lipid Peroxiode and Manganese Superoxide Dismutase with Its Genetic Polymorphism in Breast Cancer and Benign Breast Patients among Egyptian Population Sample
}

\author{
${ }^{a}$ Nagwa S. Ahmed, ${ }^{a}$ Mohamed A. Abdelmoaty' and \\ ${ }^{b}$ Omar Abd. Elraheem \\ ${ }^{\mathbf{a}}$ Departments of Biochemistry, and ${ }^{\mathbf{b}}$ General Surgery, \\ ${ }^{\mathbf{a}, \mathbf{b}}$ Faculty of Medicine, Sohag University
}

\begin{abstract}
Breast cancers are potentially life threatening malignancies in women. Current evidence indicates that free radicals and mitochondrial DNA damage play a prominent role in the development of breast cancer. Manganese superoxide dismutase $(M n S O D)$ is a major enzyme that is responsible for the detoxification of reactive oxygen species (ROS) in the mitochondria. One of the several metabolic pathways involved in breast carcinogenesis is the human polymorphism in the mitochondria targeting sequence Ala Val of the MnSOD gene. It is hypothesized that the valine to alanine substitution seems to alter transport of the enzyme into the mitochondrion, changing its efficacy in fighting oxidative stress. The present study included 24 females with breast cancer, 27 females with benign breast lesion and 23 female healthy controls. Whole blood samples were collected, part on heparin for DNA extraction which was used to assay MnSOD polymorphism by polymerase chain reaction-restriction fragment length polymorphism (PCR-RFLP) technique. The other part of blood samples was collected on plain tunes and serum together with breast tissue samples were used for estimation of lipid peroxides (LP), nitric oxide (NO) and total superoxide dismutase (SOD) activity. The results of the study showed significant elevations of serum NO mean levels in breast cancer patients (53.57 \pm 10.6 $\mu \mathrm{mol} / \mathrm{l})$ compared to both control subjects $(25.4 \pm 8.3 \mu \mathrm{mol} / \mathrm{l})$ and patients with benign breast lesions (23.6 $\pm 7.8 \mu \mathrm{mol} / \mathrm{l})$, the latter mean level is not significantly different from that of controls. NO levels in breast cancer tissues $(7.3 \pm 1.3 \mathrm{pmol} / \mathrm{mg}$ protein) were significantly higher compared to both control subjects (1.6 \pm 0.03 pmol $/ \mathrm{mg}$ protein) and patients with benign breast lesions (3.3 $\pm 0.7 \mathrm{pmol} / \mathrm{mg}$ protein), Also, the latter mean level is significantly higher compared to that of controls. Serum MDA levels in breast cancer patients $(1.58 \pm 104 \mu \mathrm{mol} / \mathrm{l})$ were not significantly different compared to both control subjects $(0.9 \pm 0.7 \mu \mathrm{mol} / \mathrm{l})$ and patients with benign breast lesions (1.07 $\pm 0.62 \mu \mathrm{mol} / \mathrm{l}), \mathrm{MDA}$ mean levels in breast cancer tissues $(244.2 \pm 23.1$ $\mathrm{pmol} / \mathrm{mg}$ protein) were significantly higher compared to both control subjects (77.4 \pm 8.3 pmole $/ \mathrm{mg}$ protein) and patients with benign breast lesions $(91.2 \pm 91.2$ pmole Img protein), , the latter mean level is not significantly different from that of controls. Serum total SOD mean activity of breast cancer patients $(145.4 \pm 24.6$ U/l) was significantly lower compared to both control subjects $(231.5 \pm 39.4 \mathrm{U} / \mathrm{l})$ and patients
\end{abstract}


with benign breast lesions $(211.1 \pm 37.4$ U/l), , the latter mean level is not significantly different from that of controls. Total SOD mean activity in breast cancer tissues $(9.3 \pm 2.7$ U/mg protein) were significantly lower compared to both control subjects (25.5 $\pm 1.1 \mathrm{U} / \mathrm{mg}$ protein) and patients with benign breast lesions $(23.1 \pm 2.3 \mathrm{U} / \mathrm{mg}$ protein), , the latter mean activity is not significantly different from that of controls. Ala/Val genotype is the most prominent in the breast cancer women (66.7\%) with odd ratio $=2.63(p<0.03)$ as compared to the Val/Val which was higher in control (69.6\%).Conclusion: It could be concluded that the individual susceptibility to breast cancer may be modulated by MnSOD polymorphism, and the combination of genetic factors with the increase of the free radicals that induce lipid peroxidation decreasing activity of enzymatic antioxidants might play an important role in the pathogenesis of breast cancer.

\section{INTRODUCTION}

Breast cancer is the second most common type of cancer after lung cancer and the fifth most common cause of cancer death among both sexes worldwide ${ }^{(\mathbf{1})}$. The etiology of breast cancer is multifactorial. Significant breast cancer risk factors include age, early age at menarche, late age of menopause, late age at first pregnancy, obesity, oral contraception, HRT (hormone replacement therapy), diet, family history, lactation and prior history of benign breast disease ${ }^{(2)}$.

Although benign breast conditions are not life- threatening as breast cancer, benign lesions of the breast are far more frequent than cancerous ones and can cause serious physical symptoms, a financial burden for health services and emotional problems for patients and families since certain benign conditions are linked with an increased risk of developing breast cancer ${ }^{(3)}$.

The development of breast cancer has been linked to the degree of oxidative stress, particularly with perturbations in the delicate balance between reactive oxygen species
(ROS) and oxidative defenses ${ }^{\natural) ~) . ~ R O S ~}$ are generated through the metabolism of estradiol, polyunsaturated fats, ethanol and calories, all which have been considered potential risk factors for breast cancer ${ }^{(5)}$. Antioxidant enzymes such as superoxide dismutase have been demonstrated to protect cells from oxidative stress. Generation of ROS has been implicated in the etiology of a diversity of human diseases, including cancer $^{(6)}$. Oxidative stress has been demonstrated to induce cell death as a result of excessive cellular damage associated with lipid peroxidation and alterations of nucleic acids and proteins, triggering apoptosis through the mitochondria ${ }^{(7)}$.

Nitric oxide (NO), which is synthesized by nitric oxide synthase, is a multi-function signaling molecule controlling vasodilatation, platelet aggregation, immunocytotoxicity and carcinogenesis ${ }^{(8,9)}$. Analysis of nitrite and nitrate has been used extensively as an index of endogenous production of NO in biological systems, with respect to various pathological processes. Reactive nitrogen species have been proposed to contribute to multistage carcinogenesis via DNA or 
tissue damage, mutations chromosomal aberrations in inflamed tissues ${ }^{(10)}$.

Lipid peroxidation (LP) is one of the most investigated consequences of reactive oxygen species (ROS) actions on membrane structure and function. The idea of lipid peroxidation as a solely destructive process has changed during the past decade. It has been shown that lipid hydroperoxides and oxygenated products of lipid peroxidation degradation as well as lipid peroxidation initiators can participate in the signal transduction cascade $^{(11,12)}$, the control of cell proliferation, and the induction of differentiation, maturation, and apoptosis. It has been shown that lipid peroxidation and ROS are triggers and essential mediators of apoptosis, which eliminates precancerous and cancerous changes ${ }^{(\mathbf{1 3})}$. In recent years, using MDA as a marker of oxidative stress, there has been a growing interest in studying the role played by lipid peroxidation in cancer progression. MDA is a low-molecular weight aldehyde that can be produced from free radical attack on polyunsaturated fatty acids ${ }^{(\mathbf{1 4})}$.

Within mitochondria, manganese superoxide dismutase (MnSOD) which is encoded by a single gene, containing five exons and located on chromosomal region $6 \mathrm{q} 25.3^{(\mathbf{1 5})}$, also it provides a major defense against oxidative damage by reactive oxygen species. Superoxide dismutase catalyzes the dismutation of the superoxide radical $\left(\mathrm{O}^{*}\right)$ to hydrogen peroxide $\left(\mathrm{H}_{2} \mathrm{O}_{2}\right)$ and oxygen $\left(\mathrm{O}_{2}\right)$. Three distinct types of superoxide dismutases have been identified in human cells: a homodimeric cytosolic
$\mathrm{CuZnSO}^{(\mathbf{1 6})}$, an extracellular homotetrameric glycosylated superoxide dismutase ${ }^{(17)}$, and a mitochondrial matrix homotetrameric manganese superoxide dismutase $(\mathrm{MnSOD})^{(\mathbf{1 8 , 1 9 )}}$. A specific region of the MnSOD protein is essential for the correct transport and processing of MnSOD by mitochondria. A genetic variant of MnSOD was identified a thymine (T) to cytosine (C) substitution in the mitochondrial targeting sequence which change the code of amino acid valine from (GTT) to that of alanine (GCT) ${ }^{(20)}$, however, this alteration may affect the cellular allocation of MnSOD into mitochondria; therefore the enzyme could leave mitochondria without full defense against superoxide radicals ${ }^{(\mathbf{2 1})}$.

The aim of the present study was to asses the association between MnSOD gene polymorphism and risk of both breast cancer and benign breast disorders, and to determine the alteration in oxidant-antioxidant status.

\section{PATIENTS AND METHODS}

\section{Patients:}

Twenty four females patients with newly detected breast cancer were diagnosed clinically, radiologicaly and confirmed by histopathological examination. They were classified using TNM system (Table1). Their ages ranged 35- 51 years. Twenty seven female patients with benign breast fibroadenoma were involved; their ages ranged 35- 47 years. All patients were recruited from Surgery Department, Sohag University Hospital during the period from January 2012 to September 
2013. The control group included twenty three healthy females without any history of breast cancer or previous benign breast problems, their age ranged 36-47 years (Table 2).

A structured questionnaire was obtained to elicit detailed information on demographic factors, menstrual and reproductive histories, hormone use, dietary habit, family history of cancer, also, current weight and height were measured, then calculating the body mass index (BMI). The University of Sohag Ethics Committee approved the study and informed consent was obtained from all participants according to the study protocol.

\section{Methods:}

Fresh tumor and benign tissues samples obtained from patients immediately after surgery. Normal breast tissue from reduction mammoplasty specimens provided as a control .The study materials were washed with saline three times, kept in vials, and stored at $-20^{\circ} \mathrm{C}$ until analysis. The tissues were weighed and homogenized under standardized conditions.

From each patients and control subjects $5 \mathrm{ml}$ venous blood samples were collected and pipetted into two tubes, one with heparin anticoagulant for the whole blood, and the other without anticoagulant, then centrifuged, the serum was separated in aliquot and stored at $-20{ }^{\circ} \mathrm{C}$ until assay.

\section{Tissue homogenization:}

All breast tissues (cancer, benign and control) were homogenized in 10 volumes of $50 \mathrm{mM}$ sodium phosphate buffer ( $\mathrm{pH}$ 7.4) for 30 sec. using a glass-Col

(TURBAX-Germany) homogenizer. The homogenate was filtered through gauze and the filtrate was centrifuged at $4000 \mathrm{rpm}$ for 15 minutes at $4{ }^{\circ} \mathrm{C}$. The resultant supernatant and the serum samples were used for measurement of:-

1-Lipid peroxidation (LP) by colorimetric method ${ }^{(22)}$ based on the reaction between MDA and TBA forms a base adduct under high temperature and acidic conditions using kits provided by Biodiagnostic Cat.No. MD 2529, Egypt).

2-Nitric oxide (NO): using Griess reagent which converts nitrite into a deep purple color which was measured at $540 \mathrm{~nm}$ according to Montgomery and Dymock ${ }^{(23)}$ using kits produced by Biodiagnostic Cat. No. 2532, Egypt.

3- Total Superoxide dismutase (SOD) activity was assayed according to the method of Nishikimi et al ${ }^{(24)}$ using kits provided by provided by Biodiagnostic Cat. No. SD 2520 Egypt

The protein content of the of the supernatant was determined by the method of Lowry et al., ${ }^{(25)}$ using kits provided by Biodiagnostic, Egypt.

\section{MnSOD Genotyping:}

Genomic DNA was extracted from whole heparinized blood samples, using CinnaPure DNA kits (Cat No. PR881612) provided CinnaPure Tehran). MnSOD genotyping was conducted using polymerase chain reaction-restriction fragment length polymorphism (CRRFLP) as described by Cai et al ${ }^{\text {(26) }}$. PCR amplification was carried out using forward primer (5'CCAGCAGGCAGCTGGCGCCGG-

3') reversed primer (5'CGTTGATGTGAGGTTCCAG-3'). 
PCR amplification kit was obtained from SinaClon BioScience (Cat No. PR8252C, Tehran). The thermal profile involved initial denaturation at $95{ }^{\circ} \mathrm{C}$ for $15 \mathrm{~min}$, followed by 35 cycles of denaturation $\left(94{ }^{\circ} \mathrm{C}\right.$ for $30 \mathrm{~s}$ ), annealing $\left(58^{\circ} \mathrm{C}\right.$ for $\left.30 \mathrm{~s}\right)$ and extension ( $72{ }^{\circ} \mathrm{C}$ for $\left.30 \mathrm{~s}\right)$, and completed with a final extension at $72^{\circ} \mathrm{C}$ for 7 minutes. RFLP technique was accomplished to detect MnSOD polymorphism using a restriction endonuclease enzyme NgoMIV (JenoBioscience Cat. No 122SGermany).

Restricted products were electrophoresed on 4\% agarose gel stained with ethidium bromide at $100 \mathrm{v}$ for 45 minutes and visualized under UV. Fragment patterns specific for MnSOD genotypes were: Ala/Val (18 bp, $89 \mathrm{bp}$ and $107 \mathrm{bp}$ ) bands, Val/Val (107 bp) band and Ala/Ala (18 bp and 89 bp)

\section{STATISTICAL ANALYSIS:}

Using SPSS software version 10, the data were statistically analyzed by one-way ANOVA and Duncan test. The association between MnSOD genotypes and the development of malignancy was examined by calculating odds ratios (OR). A $\mathrm{P}<0.05$ was considered significant.

\section{RESULTS}

Table 1: Shows the TNM classification of the investigated patients with breast cancer, their histopathological types and type of surgical therapy used.

Table 2: Shows clinical data of patients with breast cancer, those with benign breast lesion and control subjects..

Table 3; shows the mean levels of MDA, NO and SOD mean activities in the serum and tissues of patients with breast cancer and benign breast lesions and their comparison to the corresponding values of control subjects.

Table (1): TNM classification of the investigated patients with breast cancer, their histopathological types and type of surgical therapy used

\begin{tabular}{|c|c|c|c|c|c|c|c|}
\hline \multirow[b]{2}{*}{$\begin{array}{c}\text { TNM } \\
\text { staging }\end{array}$} & \multirow[b]{2}{*}{$\begin{array}{l}\text { No. of } \\
\text { cases }\end{array}$} & \multicolumn{3}{|c|}{ Surgical treatment } & \multicolumn{3}{|c|}{ Histopathological study } \\
\hline & & $\begin{array}{c}\text { Breast } \\
\text { conservative } \\
\text { surgery }\end{array}$ & $\begin{array}{l}\text { Modified } \\
\text { radical } \\
\text { mastectomy }\end{array}$ & $\begin{array}{c}\text { Simple } \\
\text { Mastectomy }\end{array}$ & $\begin{array}{c}\text { Ductal } \\
\text { carcinoma }\end{array}$ & $\begin{array}{l}\text { Lobular } \\
\text { carcinoma }\end{array}$ & $\begin{array}{l}\text { Medullary } \\
\text { carcinoma }\end{array}$ \\
\hline Stag I & 1 & 1 & - & - & 1 & - & - \\
\hline Stag II & 17 & 5 & 12 & - & 13 & 3 & 1 \\
\hline Stage III & 4 & - & 4 & - & 3 & 1 & - \\
\hline Stage IV & 2 & - & 1 & 1 & 2 & - & - \\
\hline Total $(\%)$ & 24 & $6(25 \%)$ & $17(71 \%)$ & $1(4 \%)$ & $19(79 \%)$ & $4(17 \%)$ & $1(4 \%)$ \\
\hline
\end{tabular}


Table 2: Clinical data of patients with breast cancer, those with benign breast Lesions and control subjects.

\begin{tabular}{|c|l|l|l|}
\hline General characteristics & $\begin{array}{l}\text { Breast cancer } \\
\text { N 24 }\end{array}$ & $\begin{array}{l}\text { Benign } \\
\text { Breast } \\
\text { N 27 }\end{array}$ & Control \\
\hline Age (years \pm SD) & $43.7 \pm 8.7$ & $41.8 \pm 6.3$ & $40.3 \pm 4$ \\
\hline Menopausal status & $5(21 \%)$ & $17(63 \%)$ & $16(70 \%)$ \\
\hline Premenopausal & $19(79 \%)$ & $10(37 \%)$ & $7(30 \%)$ \\
\hline Postmenopausal & $29.5 \pm 4.5$ & $27.95 \pm 3.22$ & $27.64 \pm 1.12$ \\
\hline $\mathrm{BMI}\left(\mathrm{Kg} / \mathrm{m}^{2}\right)$
\end{tabular}

Table (3): The mean levels of MDA, NO and SOD mean activities in the serum and breast tissues of patients with breast cancer and benign breast lesions and their comparison to the corresponding values of control subjects

\begin{tabular}{|c|c|c|c|}
\hline Parameters & $\begin{array}{l}\text { Breast } \\
\text { cancer }\end{array}$ & Benign breast & Control \\
\hline Serum NO $(\mu \mathrm{mol} / \mathrm{l})$ & $53.57 \pm 10.6^{*}$ & $23.60 \pm 7.89^{\infty}$ & $25.4 \pm 8.3$ \\
\hline Serum MDA, $\quad(\mu \mathrm{mol} / \mathrm{l})$ & $1.58 \pm 1.04$ & $1.07 \pm 0.62$ & $0.9 \pm 0.7$ \\
\hline Serum SOD, $\quad(\mathrm{U} / \mathrm{I})$ & $145.4 \pm 24.6^{*}$ & $211.1 \pm 37.4^{\infty}$ & $231.5 \pm 39.4$ \\
\hline Tissue NO, $\quad\left(\mathrm{pmol} / \mathrm{mg}^{-1}\right.$ protein $)$ & $7.3 \pm 1.3^{*}$ & $3.3 \pm 0.7^{\infty}$ & $0.6 \pm 0.03^{\circledR}$ \\
\hline Tissue MDA, $(\mathrm{pmol} / \mathrm{mg}$ protein $)$ & $244.2 \pm 23.1^{*}$ & $91.2 \pm 15.8^{\infty}$ & $77.4 \pm 8.3$ \\
\hline Tissue SOD , (U/mg protein) & $9.3 \pm 2.7^{*}$ & $23.1 \pm 2.3^{\infty}$ & $25.5 \pm 1.1$ \\
\hline
\end{tabular}

Table (3) showed significant elevations of serum NO mean levels in breast cancer patients compared to both control subjects and patients with benign breast lesions the latter mean level is not significantly different from that of controls. NO levels in breast cancer tissues were significantly higher compared to both control subjects and patients with benign breast lesions also the latter mean level is significantly higher compared to that of controls. Serum MDA levels in breast cancer patients were not significantly different compared to both control subjects and patients with benign breast lesions. MDA mean levels in breast cancer tissues were significantly higher compared to both control subjects and patients with benign breast lesions, the latter mean level is not significantly different from that of controls. Serum total SOD mean activity of breast cancer patients was significantly lower compared to both control subjects and patients with benign breast lesions, the latter mean level is not significantly different from that of controls. Total SOD mean activity in breast cancer tissues were significantly lower compared to both control subjects and patients with benign breast lesions, the latter mean activity is not significantly different from that of controls. 


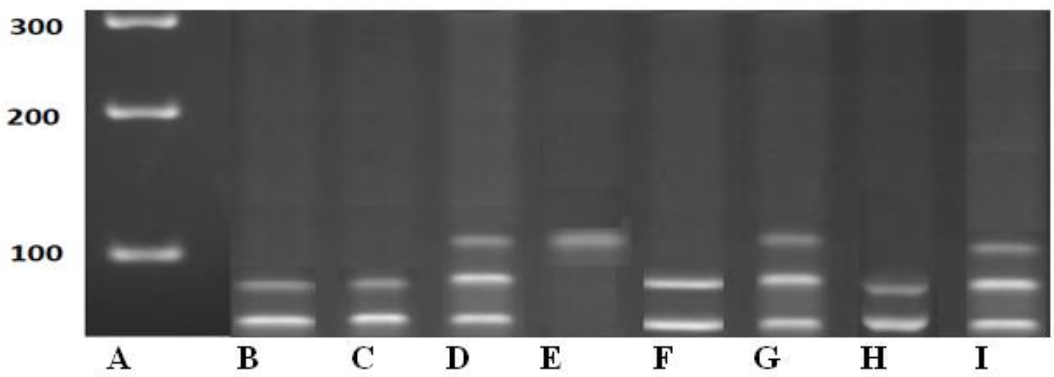

Fig.(1): Agarose gel electrophoresis of restricted amplified samples for genotyping assay (A) lane DNA ladder, (B, C, F and H) lanes showing two digested bands at 89 and $18 \mathrm{bp}$ represent Ala/Ala genotype, (D, G and I) lanes showing three digested bands at 107, 89 and 18 bp represent Ala/Val genotype and (E) lane showing single undigested band at 107 represents $\mathrm{Val} / \mathrm{Val}$ genotype.

Table (4): MnSOD genotypes in patients with breast cancer, benign breast lesion and control subjects.

\begin{tabular}{|l|c|c|c|}
\hline MnSOD Genotype & Breast cancer & $\begin{array}{l}\text { Benign breast } \\
\text { Lesions }\end{array}$ & Control \\
\hline Ala/Ala & $3(12.5 \%)$ & $8(29.6 \%)$ & $6(26.1 \%)$ \\
\hline Val/Val & $5(20.8 \%)$ & $11(40.8 \%)$ & $16(69.6 \%)$ \\
\hline Ala/Val & $16(66.7 \%)$ & $8(29.6 \%)$ & $1(4.3 \%)$ \\
\hline
\end{tabular}

Table (4) demonstrated that in breast cancer patients $\mathrm{Ala} / \mathrm{Val}$ is the most prominent $(66.7 \%)$, in benign breast lesions, the most prominent was $\mathrm{Val} / \mathrm{Val}$ (40.8\%), and in the control subjects, the most prominent was also, $\mathrm{Val} / \mathrm{Val}(69.6 \%)$.

Table 5: Odd ratios of MnSOD gene polymorphisms in breast cancer patients

\begin{tabular}{|l|l|l|}
\hline Polymorphism in one or two allele & Odds ratio & P-value \\
\hline Ala/Ala & 0.74 & 0.4 \\
\hline Ala/Val & 2.63 & 0.03 \\
\hline Val/Val & 0.2 & 0.3 \\
\hline
\end{tabular}

Table (5) demonstrated that in breast cancer patients Ala/Val polymorphism id the only significant $(\mathrm{P}=\mathbf{0 . 0 3})$.

In investigation of $\mathrm{Ala} / \mathrm{Val}$ polymorphism odd ratio was significant higher in breast cancer patients $(\mathrm{p}=0.03)$ as shown in table (5). 


\section{DISCUSSION}

Breast cancer is one of the most common neoplasm in women and is a leading cause of cancer related deaths

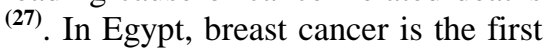
neoplastic disease in females representing $37 \%$ of all female cancers as represented by National Cancer Institute, Cairo University ${ }^{(28)}$. Although a number of significant advances have been made, the molecular mechanism involved in breast cancer pathogenesis still remain unclear to date.

Oxidative stress is considered to be involved in the pathophysiology of all cancers, especially breast cancer ${ }^{(29)}$. Oxidative stress caused by increased free radical generation and /or decreased antioxidant levels in the target cells and tissues has been suggested to play important role in carcinogenesis ${ }^{(30)}$. Free radicals are capable of altering all major classes of biomolecules such as lipids, nucleic acids and proteins, with changes in their structure and function and function $^{(31)}$. Prime targets of free radicals are the polyunsaturated fatty acids in cell membranes and their interaction results in lipid peroxidation changes in the concentration of lipid peroxidation have been reported in breast cancer ${ }^{(2)}$.

Presentation of nitric oxide in human serum and tissue extracts is a well known phenomenon which points to a crucial role of nitric oxide in physiological and pathological processes. NO is readily oxidized to nitrite and nitrate in biological systems. It exhibits a dual role, with regard to the complex mechanism of tumor invasion and metastasis. It could either mediate tumorocidal activity or promote tumor growth ${ }^{(32)}$. In the current study, there is significant higher mean levels of both serum and tissue NO in breast cancer patients compared to those of benign breast lesions and to controls, this result agrees with the result of Thomsen et al. (33) who showed increased nitrate and nitrite levels in serum and tissue of breast carcinoma compared to those of the benign breast disease due to increased expression of NO synthase and may be in response to inflammation.

Lipid peroxidation is a natural consequence of metabolic processes in the cell, occurring via initiation, propagation, and termination reaction $^{(34)}$. Recently GagoDominguez et $\mathrm{al}^{\left({ }^{(35)}\right.}$ proposed the hypothesis that lipid peroxidation represents a protective mechanism in breast cancer, and reviewed the evidence of the role of this process on established reproductive, hormonal, and non-hormonal factors for breast cancer. Likewise, the women with untreated postmenopausal breast cancer had higher amounts of lipid peroxides with a concomitant, lower activity of antioxidant enzymes than their respective premenopausal breast cancer counterpart ${ }^{(36)}$. It has been hypothesized, that lipid peroxidation may increase breast cancer risk $^{(35)}$ .Our results agree with this hypothesis and there is significant increase of tissue MDA in breast cancer than control and benign breast lesions, also, Faber et al ${ }^{(37)}$, have shown that the patients with breast cancer have higher MDA levels when compared to 
controls .Also Marnett ${ }^{(38)}$, has reported that MDA is a naturally occurring product of lipid peroxidation and prostaglandin biosynthesis that is mutagenic and carcinogenic. It reacts with DNA to form adducts to deoxyguanosine and deoxyadenosine. The major adduct to DNA is a pyrimidopurinone. Gerber et al. ${ }^{(39)}$, have reported that patients with breast cancer significantly lower plasma MDA compared to healthy controls. A consideration of the literature on animal and in vitro, studies suggests that an influence on breast cancer protection relates to the generation of lipid peroxidation products. The beneficial or detrimental effects of lipid peroxidation on cellular structures may depend on several factors, such as baseline levels of ROS (inducers of lipid peroxidation), and the type of tissue, that is, slowly versus rapidly proliferating tissue, in which ROS exert their action ${ }^{(35)}$.

SOD is of marked pathophysiological importance. It was studied primarily as a defense mechanism against the consequences of free radical production ${ }^{(\mathbf{4 0})}$. A recent study demonstrates a novel therapeutic strategy to inhibit cell death and apoptosis caused by ROS, via increasing antioxidant potential, which can be overcome by treatment with SOD modulators ${ }^{(41)}$. The inconsistency in the result is likely due to the heterogeneity of the tumor tissue $^{(\mathbf{4 2})}$, and the method which was used to measure this enzyme activity. However, the obtained data remain unclear because SOD activity varies greatly, according to the different conditions in each study. Since the causes and biochemical profile of breast cancer are not yet fully known and there is no clear mechanism by which oxygen radicals may affect the outcome of breast cancer. Our result showed that there is significant decrease of SOD in breast cancer in comparison to control, a result which agrees with those of Abiaka et al. ${ }^{(43)}$ who reported decreased SOD in erythrocytes of patients with breast cancer. However Portakal et al. (44) found that total SOD activity in breast tumor tissues was significantly higher than that in corresponding cancer-free tissues. Furthermore, oxidative DNA damage is reportedly increased in breast cancer tissue relative to normal breast ${ }^{(45)}$.

MnSOD, one of the major antioxidant enzymes, catalyzes the dismutation of superoxide radicals to $\mathrm{H}_{2} \mathrm{O}_{2}$ and oxygen in mitochondria and thus constitutes first-line defense against ROS in mitochondria. Hence, it is conceivable that structural and/or functional polymorphisms of MnSOD gene are of immense importance in the maintenance of ROS levels in cell. Low expression of MnSOD has often been accounted for different types of cancer formation; the association observed from our results could be explained by some biochemical evidences that suggests association between breast cancer and oxidative stress metabolism ${ }^{(\mathbf{4 6})}$.

The most commonly studied polymorphism of MnSOD is $\mathrm{Val}^{\mathbf{1 6}} \mathrm{Ala}$ on mitochondrial target sequence. It is a single nucleotide polymorphism (SNP) in codon 16. A substitution of $\mathrm{T}$ to $\mathrm{C}$ at nucleotide 47 changes the encoded amino acid from Val (GTT) to Ala (GCT) on the 16th residue of 
24-amino acid signal sequence that helps in targeting the nascent protein to mitochondria. This residue is 9amino acid upstream of the cleavage site, hence, has often been designated as $\mathrm{Ala}^{\mathbf{9}}$ Val polymorphism ${ }^{(21)}$. A newly synthesized MnSOD is transported to mitochondria where it is assembled into a homotetramer. ShimodaMatsubayashi et al. ${ }^{(20)}$ predicted that Val allele would encode a $\beta$-sheet conformation rather than a preferred $\alpha$-helical structure of MnSOD precursor protein that leads to an impaired transport of MnSOD to mitochondria. Sutton et al. ${ }^{(47)}$ found that the Ala form of MnSOD is targeted into the mitochondria, whereas the Val form is partially arrested in the inner mitochondrial membrane. Their study revealed that Ala form of MnSOD was 30\% to $40 \%$ more efficiently localized to the mitochondria than the Val form. In view of these findings, it is expected that the Val form is likely to be associated with higher levels of ROS and thus predisposes to a greater risk of cancer.

Our result shows that MnSOD genotyping revealed that $\mathrm{Ala} / \mathrm{Val}$ genotype had the highest distribution for cancer group $(66.7 \%)$ and were in agreement with the findings of Ambrosone et al. ${ }^{(5)}$, Mitrunen e $t$ al ${ }^{(48)}$ and Cai et al ${ }^{(26)}$, which all based on the fact that the Ala-containing MnSOD is transported more efficiently through the mitochondrial membrane ${ }^{(47)}$, were explained by the possible highly active Ala-containing MnSOD that could cause accumulation of $\mathrm{H}_{2} \mathrm{O}_{2}$ in mitochondria at least in the absence of $\mathrm{H}_{2} \mathrm{O}_{2}$ scavenging enzymes such as glutathione peroxidase and catalase, which could lead to oxidative damage and consequently cancer.

It could be concluded that variation in key antioxidant enzymes with high level of oxidative stress are long speculated risk factors for the genetic susceptibility for cancer development. Genetic polymorphism in MnSOD gene may be associated with increased risk of breast cancer, however, studies with more patients and oxidative stress-related parameters are required, also, exogenous administration of antioxidant, may be helpful in the management of breast cancer.

In summary, the current study investigated the relationship between high serum $\mathrm{NO}$ and tissue $\mathrm{NO}$ and MDA with low serum and tissue SOD and ALA/VAL MnSOD polymorphism in breast cancer. It is recommended to investigate the correlation of these varieties with each specific breast cancer cell types

\section{REFERENCES}

1. World Health Organization, International Agency for Research on Cancer (2002): IARC handbook of cancer prevention. Breast Cancer Screening. IARC Press, Layon pp1-7.

2. Go"nenc, A, Erten D,Aslan S,Akinei M, Simsek $B$ and Torun M(2006): Lipid peroxidation and antioxidant status in blood and tissue of malignant breast tumor and benign breast disease. Cell Biol. Int.,; 30(4):376-80.

3. Guray M. and Sahin, A. A. (2006): Benign breast Diseases: 
Classification, Diagnosis, and Management. Oncologist, 11(5):435-449.

4. Ambrosone CB (2000): Oxidants and antioxidants in breast cancer. Antioxid. Redox. Signal, 2(4):903-17.

5. Ambrosone CB, Freudenheim JL, Thompson PA, Bowman E, Vena JE, Marshall JR, Graham $S$, Laughlin $R$, Nemoto $T$, Shields PG(1999): Manganese superoxide dismutase (MnSOD) genetic polymorphisms, dietary antioxidants, and risk of breast cancer. Cancer Res., 59(6):602-6.

6. St Clair DK, Wan XS, Kuroda M, Vichitbandha S, Tsuchida E,Urano M(1997): Suppression of tumor metastasis by manganese superoxide dismutase is associated with reduced tumorigenicity and elevated fibronectin. Oncol. Rep., 4(4):753-757.

7. Mignotte $\mathbf{B}$, Vayssiere JL (1998): Mitochondria and apoptosis. Eur. J. Biochem., 252(1):1-15.

8. Conner EM, Grisham MB.(1995): Nitric oxide: biochemistry, physiology and pathophysiology. Methods Enzymol., 7:3-13.

9. MacAllister RJ, Vallance $\mathbf{P}$. (1996): The L-arginine: nitric oxide pathway in the human cardiovascular system. J. Int .Fed. Clin. Chem., 8:152-8.

10. Halliwell B, Gutteridge JMC (1999): Free radicals in biology and medicine. 3rd ed.UK: Oxford Science Publications.

11. Blokhina $O$, Virolainen $E$, Fagerstedt KV (2003): Antioxidants, oxidative damage and oxygen deprivation stress: a review. Ann. Bot. (Lond), 91 (Spec No):179-194.

12. Tarchevskii I (1992): Regulatory role of degradation of biopolymers and lipids. Fiziologiya Rastenii., 39:12151223.

13. Salganik RI (2001): The benefits and hazards of antioxidants: controlling apoptosis and other protective mechanisms in cancer patients and the human population. J. Am. Coll. Nutr., 20 (Suppl. 5):464S-472S; discussion 473S-475S.

14. Seven A, Erbil Y, Seven R.(1998): Breast cancer and benign breast disease patients evaluated in relation to oxidative stress. Cancer Biochem. Biophys., 16(4):333-45.

15. Abdel-Fattah M.S, Atoumb M, Abdel-Rahmanc S, Alobousd A(1995): Genetic Polymorphism of Manganese Superoxide Dismutase (MnSOD) Among Breast Cancer and Benign Breast Patients in Jordan: A Preliminary Study. Jordan Journal of Biological Sciences: 2:No.2:7782.

16. McCord JM, Fridovich I(1969): Superoxide dismutase: An enzymic function for erythrocuprein (hemocuprein). J. Biol. Chem., 244(22):6049-6055.

17. Marklund SL(1982): Human copper-containing superoxide dismutase of high molecular weight. Proc. Natl. Acad. Sci. USA 79(24):7634-8.

18. Weisiger RA, Fridovich I(1973): Mitochondrial superoxide dismutase: Site of synthesis and intramitochondrial localization. J. Biol. Chem., 248(13):4793-6. 
19. Holley AK, Dhar SK, Xu Y, St Clair DK (2012): Manganese superoxide dismutase: beyond life and death. Amino Acids, 42(1): 139-58.

20. Shimoda- Matsubayashi S, Matsumine $H$, Kobayashi $T$, Nakagawa-Hattori Y, Shimizu, Y. and Mizuno, Y (1996): Structural dimorphism in the mitochondrial targeting sequence in the human manganese superoxide dismutase gene: A predictive evidence for conformational change to influence mitochondrial transport and a study of allelic association in Parkinson's disease. Biochem. Biophys. Res. Commun., 226(2): 561-565.

21. Rosenblum JS, Gilula, NB and Lerner, RA (1996): On signal sequence polymorphisms and diseases of distribution. Proc. Natl. Acad. Sci., 93(9):44714473.

22. Satoh K.(1978): Serum lipid peroxide in cerebrovascular disorders determined by a new colorimetric method. Clin. Chim. Acta 90(1):37- 43.

23. Montgomery HAC and Dymock JF.(1961): The determination of nitrite in water. Analyst 86: 414 $-16$

24. Nishikimi $M$, Appaii $N$ and Yogi K (1972): The occurrence of superoxide anion in the reaction of reduced phenazine methosulfate and molecular oxygen. . Biochem. Bioph. Res. Common.; 46(2): 849 - 54.

25. Lowry OH, Rosebrough NJ, Farr AL, Randall RJ (1951): Protein measurement with Folin phenol reagent. J. Biol. Chem., 193: 265-75.
26. Cai Q, Shu XO. Wen W, Cheng JR, Dai Q, Gao YT, and Zheng W (2004):. Genetic polymorphism in the manganese superoxide dismutase gene, antioxidant intake, and breast cancer risk: results from the Shanghai Breast Cancer Study. Breast Cancer Res., 6(6): R64755.

27. Murray CJ, Lopez AD (1997): Mortality by cause for eight regions of the world: global burden of disease study. Lancet 349(9061) :1269-76.

28. Elatar, I. (2002): Cancer registration, NCI Egypt (2001) Cairo, Egypt, National Cancer Institute. Retrieved April 1, /S1110-362(12)00058-

29. Reed JC and Pellecchia $M$, (2005): Apoptosis -based therapies for hematologic malignancies. Blood 106(2):40818.:

30. Aghvami T, Djalali $M$, Kesharvarz A MR Sadeghi, Zeraati H, Sadrzadeh Yeganeh H, Negahdar $M$ (2006): Plasma level of antioxidant vitamins and lipid peroxidation in breast cancer patients. Iran J. Publ. Health 35(1): 42-7.

31. Guyton KZ, Kensler TW (1993): Oxidative mechanism in carcinogenesis. Br. Med. Bull., 49(3):523-44.

32. Lala PK (1998): Significance of nitric oxide in carcinogenesis, tumor progression and cancer therapy. Cancer Metastasis Rev., 17(1):1-6.

33. Thomsen LL, Miles DW, Happerfield L, Bobrow LG, Knowles RG, Moncada S (1995): Nitric oxide synthase 
activity in human breast cancer. Br. J.Cancer 72(1):41-4.

34. Schaich, KM (1992): Metals and lipid oxidation: Contemporary issues. Lipids 27(3):209-18.

35. Gago-Dominguez $M$, Castelao JE, Pike MC, Sevanian A, Haile RW(2005): Role of lipid peroxidation in the epidemiology and prevention of breast cancer. Cancer Epidemiol.. Biomarkers Prev., 14(12):2829-39.

36. Thangaraju $M$, Ilanchezhian $\mathrm{S}$, Ezhilarasi R, Sachdanandam P. (1993): Lipid peroxidation and antioxidative enzyme levels in tamoxifen treated breast cancer women in relation to the menopausal status of the patients. Med. Sci. Res., 21(19):721-3.

37. Faber M, Coudray C, Hida $H$, Mousseau M, Favier A.(1995):Lipid peroxidation products, and vitamin and trace element status in patients with cancer before and after chemotherapy, including adriamycin. A preliminary study. Biol Trace Elem. Res., 47(1-3): 117-23.

38. Marnett LJ. (1999):Lipid peroxidation-DNA damage by malondialdehyde. Mutat. Res. 424(1-2): 83-95.

39. Gerber $M$, Astre $C$, Ségala $C$, Saintot M, Scali J, SimonyLafontaine J, Grenier J, Pujol H.(1997): Tumor progression and oxidant-antioxidant status. Cancer Lett 114(1-2): 211-4.

40. Nakamura $Y$, Gindhart TD, Winterstein D, Tomita I, Seed JL, Colburn NH. (1988): Early superoxide dismutase-sensitive event promotes neoplastic transformation in mouse epidermal JB6 cells.

Carcinogenesis 9(2): 203-7.

41. Aird KM, Allensworth JL, Batinic-Haberle I, Lyerly HK, Dewhirst MW, Devi GR. (2012): ErbB $1 / 2$ tyrosine kinase inhibitor mediates oxidative stress-induced apoptosis in inflammatory breast cancer cells. Breast Cancer Res. Treat., 132(1): 109-19.

42. Punnonen K, Ahotupa M, Asaishi K, Hyöty M, Kudo R, Punnonen R. (1994): Antioxidant enzyme activities and oxidative stress in human breast cancer. J. Cancer Res. Clin. Oncol., 120(6): 374-7.

43. Abiaka C, Al-Ayadi F, Al-Sayer H, Gulshan S, Behbehani A, Farghally M.(2002): Activities of erythrocyte antioxidant enzymes in cancer patients. J. Clin. Lab .Anal., 16(4);167-71.

44. Portakal O, Ozkaya O, Erden Inal M, Bozan B, Koşan M, Sayek I (2000): Coenzyme Q10 concentrations and antioxidant status in tissues of breast cancer patients.

Clin.Biochem.: 33(4):279-84.

45. Tamimi RM, Hankinson SE, Spiegelman D, Colditz GA, Hunter DJ (2004): Manganese superoxide dismutase polymorphism, plasma antioxidants, cigarette smoking, and risk of breast cancer. Cancer Epidemiol. Biomarkers Prev., 13(6):989 - 96.

46. Musarrat, J.; Arezina-Wilson, J.; Wani, A.A (1996): Prognostic and etiological relevance of 8hydroxyguanosine in human breast carcinogenesis. Eur. J. Cancer 32A(7): 1209-14 . 
47. Sutton, A. Khoury, H. PripBuus, C. Cepanec, C. Pessayre, D. and Degoul, F. (2003): The $\mathrm{Ala}^{16} \mathrm{Val}$ genetic dimorphism modulates the import of human manganese superoxide dismutase into rat liver mitochondria. Pharmacogenetics 13(3):145-157.
48. Mitrunen $K$, Sillanpää $P$, Kataja V, Eskelinen M, Kosma VM, Benhamou S, Uusitupa M, Hirvonen A.(2001): Association between manganese superoxide dismutase (MnSOD) gene polymorphism and breast cancer risk. Carcinogenesis 22(5):82729.

\section{أكسيد التيتريك وبروكسيد الدهون و التعداد الثكلى لجين مانحنيز- سوبراكسيد

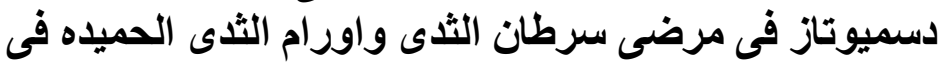 عينة من سكان مصر الثر واور

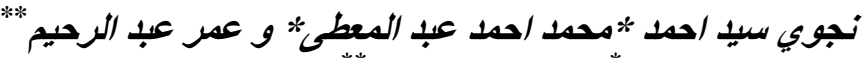 \\ قسمي الكيمباء الحيوية الطبية" و الجر احة العامة *قدئ بكليه الطب البشرى- جامعة سو هاج}

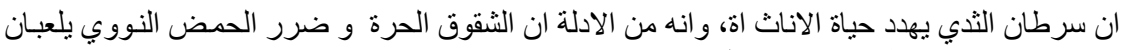

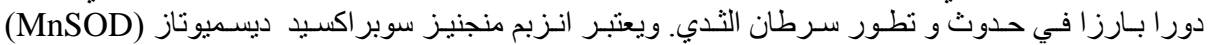

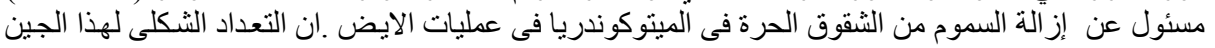

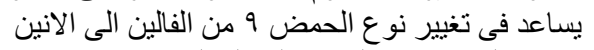

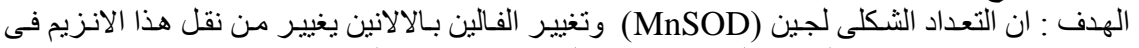

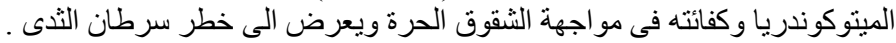

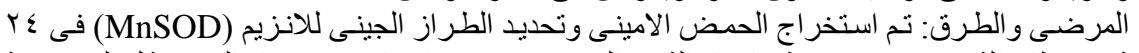

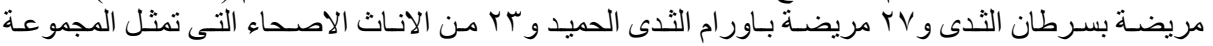

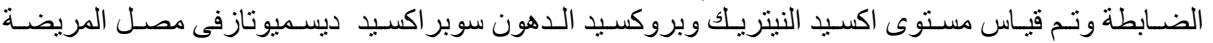
و انسجة الثذى على جهاز قياس الالوان الطيفي.

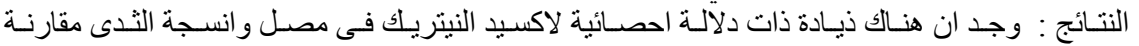

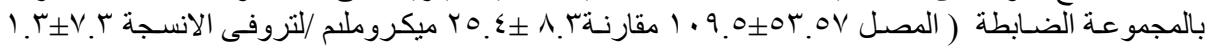

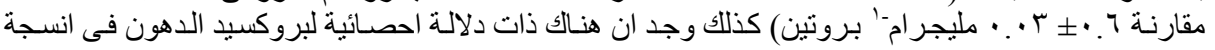

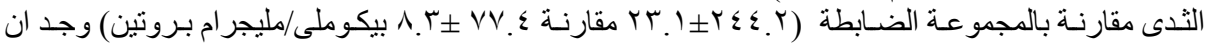

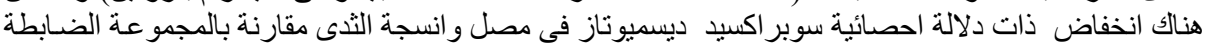

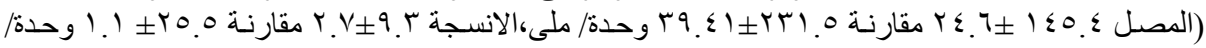

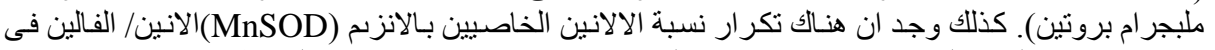

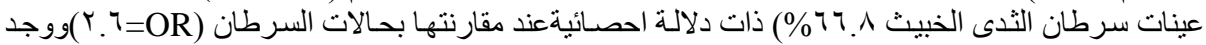

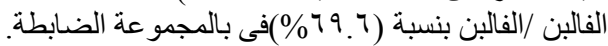

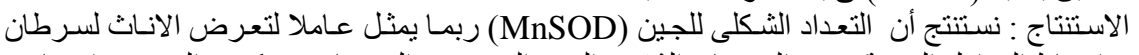

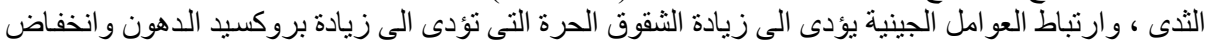
فى نشاط مضادات الاكسدة الانزيمية في سرطان الثى رابدى الثئ. 